\title{
POTENSI BAKTERI LAUT UNTUK BIOREMEDIASI
}

\author{
Oleh \\ Nur Fitriah Afianti ${ }^{1)}$
}

\section{ABSTRACT}

\section{POTENCY OF MARINE BACTERIA FOR BIOREMEDIATION. Marine} bacteria have a high abundance on variation as well as the qenes, so it can be used in various aspects, including the prevention of marine pollution through bioremediation. High genetic variations provide a source of marine bacteria which has decompose-various substances capability. Various studies have been conducted to determine the potential of marine bacteria in degrading pollutants, including degradation of hydrocarbons, PAH, plastic, PCB and removal of heavy metal. Recombination through the insertion of the marine bacteria's gene coding enzyme has been also performed on indigenous actinomycetes on soil.

\section{PENDAHULUAN}

Bakteri merupakan salah satu jenis mikroorganisme yang memiliki kelimpahan sangat tinggi di alam, baik dari segi jumlah maupun jenisnya. Bakteri tersebar dalam berbagai lingkungan baik di darat, laut, gunung api, samudera antartika bahkan di kawah gunung api. Diversitas bakteri yang tinggi di alam ini merupakan hasil dari kemampuan beradaptasi yang tinggi dengan kondisi yang ekstrim untuk mendukung fungsi fisiologisnya (Madigan et al., 2008). Tingginya variasi genetik sering kali menyebabkan hadirnya strain bakteri yang baru.

Sebanyak 71\% permukaan bumi merupakan wilayah perairan, dimana $97 \%$ air di bumi adalah saline. Kondisi abiotik di lingkungan laut menyediakan kondisi alam yang sangat bervariatif, mulai dari salinitas, suhu, $\mathrm{pH}$, arus dan angin. Sebagai contoh, bakteri laut umumnya memiliki rentang suhu pertumbuhan yang lebih luas dibandingkan bakteri darat. Hal ini juga menyebabkan bakteri pada ekosistem laut lebih adaptif pada perubahan kondisi lingkungan yang bervariasi. Sehingga, pemanfaatannya untuk kepentingan manusia menjadi lebih luas tanpa perlu melakukan manipulasi genetika (Dash et al., 2013). Setiap jenis bakteri di alam memiliki peranannya masing-masing. Secara umum, bakteri berperan sebagai konsumen, pengurai dan pemelihara siklus biogeokimia. Kemampuan bakteri dalam mengurai berbagai pencemar organik menjadi senyawa yang tidak berbahaya mulai banyak diperhatikan sebagai alat untuk mengolah lingkungan tercemar secara biologis. Bakteri dapat dimanfaatkan untuk mengatasi pencemaran yang terjadi di laut yang disebabkan oleh tumpahan minyak, cemaran logam berat, pestisida dan berbagai polutan organik lainnya (Madigan et al., 2008).

\footnotetext{
$\overline{{ }^{1)} \text { Pusat Penelitian Oseanografi - LIPI }}$
} 
Berbagai kontaminan yang berbahaya dalam lingkungan laut baik pada kolom air maupun sedimen dapat menyebabkan kerusakan ekosistem laut dan juga masalah bagi kesehatan manusia. Penurunan kualitas lingkungan pesisir dan laut ini dapat terjadi, karena masukan nutrien dan bahan organik dari aktivitas darat. Lingkungan laut menjadi tujuan akhir dari limbah-limbah di darat, baik dari limbah industri peleburan logam, limbah industri petrokimia, limbah industri kertas dan paper, limbah tekstil, aktivitas antropogenik dan limbah pertanian. Aktivitas pertambangan di laut juga merupakan salah satu sumber utama polusi di laut, terutama polutan berupa senyawa organik. Insiden tumpahan minyak yang terjadi secara tidak sengaja sering kali menyebabkan kerusakan lingkungan dan kematian biota laut. Selain itu, beberapa senyawa berbahaya juga dapat masuk ke lingkungan perairan seperti, agen pengawet, pertisida, logam berat, limbah tekstil yang mengandung pewarna, bahkan limbah industri farmasi. Beberapa polutan bersifat karsinogenik dan neurotoksik yang sangat berbahaya bagi kesehatan manusia. Senyawa organofosfat digunakan sebagai aditif minyak bumi, pestisida, dan plasticizer band berpengaruh terhadap sindrom degeneratif sistem saraf dan merupakan mutagen kuat, sehingga dapat menyebabkan karsinogenesis dan penyimpangan kromosom (Singh, 2009; Sirotkina et al., 2012).

Bioremediasi didefinisikan sebagai proses penanggulangan senyawa pencemar melalui penguraian atau reduksi limbah organik maupun anorganik yang bersifat toksik di lingkungan secara biologis menjadi senyawa lain yang tidak atau kurang berbahaya, seperti karbon dioksida atau beberapa gas lain, senyawa anorganik dan air. Kelebihan metode bioremediasi dengan metode lain yaitu penggunaannya yang lebih ramah lingkungan. Menurut US EPA (United States Environmental Protection Agency), agen bioremediasi didefinisikan sebagai kultur mikroorganisme, enzim atau stimulan berupa nutrien yang dapat meningkatkan laju biodegradasi. Penggunaan mikroorganisme dinilai lebih efektif karena kapasitas degradasi kontaminan yang tinggi menjadi senyawa tidak berbahaya atau kurang berbahaya (Leung, 2004). Oleh karena itu, potensi bakteri laut untuk aplikasi bioremediasi telah banyak digali dalam upaya mengatasi pencemaran di lingkungan perairan laut. Beberapa hasil penelitian menunjukkan kemampuan bakteri laut dalam mendegradasi maupun mereduksi berbagai senyawa pencemar.

\section{DEGRADASI HIDROKARBON}

Hidrokarbon merupakan senyawa dominan yang terkandung di dalam minyak. Tumpahan minyak dari kapal tangker maupun kebocoran minyak akibat penggunaan bahan bakar minyak dapat menyebabkan terjadinya pencemaran hidrokarbon di lingkungan perairan. Minyak bumi sebagai sumber utama senyawa hidrokarbon merupakan senyawa yang relatif recalcitrant sehingga tidak mudah didegradasi dalam waktu yang singkat (Barnum, 2005). 
Benzena, toluene, etilbenzena dan isomer xylena atau lebih dikenal dengan BTEX merupakan senyawa hidrokarbon dalam minyak bumi yang bersifat mutagenik dan karsinogenik (Fahruddin, 2004).

\section{Mikroorganisme memiliki} peranan penting dalam mendegradasi senyawa hidrokarbon secara sempurna. Telah banyak diketahui mengenai mikroorganisme terutama bakteri yang dapat mendegradasi hidrokarbon minyak bumi. Kemampuan bakteri dalam mendegradasi minyak melibatkan kerja dari enzim alkana hidroksilase yang dikode oleh gen alkB. Genus Alcanivorax adalah kelompok bakteri yang terkenal sebagai pendegradasi minyak. Darmayati et al. (2008) telah melaporkan bahwa bakteri genus Alcanivorax spp. dari Teluk Jakarta, memiliki kemampuan dalam mendegradasi hidrokarbon. Kemampuan yang sama juga dimiliki oleh spesies Bacillus aminovorans, Bacillus cereus, Pseudomonas alcaligens, dan Alcaligenes faecalis (Widjajanti et al., 2013). Teramoto et al. (2011) juga telah menemukan novel bakteri pendegradasi minyak Oleibacter marinus gen. nov., sp.nov. dari air laut Teluk Jakarta.

\section{DEGRADASI PAH}

PAH atau polisiklik aromatik hidrokarbon merupakan molekul organik yang terdiri dari dua atau lebih cincin benzena yang bergabung dalam bentuk linier atau kelompok. Lebih dari $70 \%$ PAH berasal dari aktivitas yang berhubungan dengan minyak. Selain itu, juga berasal dari industri lainnya seperti produksi pelarut, pestisida, plastik, cat, dan bahan celup. PAH yang sering ditemukan adalah naftalena, antrasena, dan senyawa yang lebih kompleks seperti pirena dan benzo(a)pirena. PAH diketahui bersifat toksik, mutagenik, dan beberapa senyawa antaranya juga bersifat karsinogen terhadap manusia (Kanaly \& Harayama, 2000).

Degradasi senyawa PAH dipengaruhi oleh kompleksitas struktur kimia senyawa tersebut dan tingkat adaptasi enzim. Oxygnenase dan dehydrogenase merupakan enzim yang dapat mendegradasi PAH (Haritash \& Kaushik, 2009). Todorova et al. (2014) mengungkapkan bahwa pada sedimen di pantai Laut Hitam yang mengalami pencemaran PAH kronis telah terjadi peningkatan keberadaan kelompok bakteri $\alpha$-dan $\gamma$-Proteobacteria dibandingkan daerah tidak tercemar yang umumnya prevalensi kelompok bakteri Actinobacter. Oleh karena itu, $\alpha$-Proteobacteria dapat berfungsi sebagai bioindikator pencemaran minyak kronis. Pseudomonas monteilii P26, Pseudomonas stutzeri N3, dan Pseudomonas xanthomarina N12 yang diisolasi dari pantai tercemar Patagonian juga menunjukkan kemampuan mendegradasi naftalena dan fenantrena, namun tidak dapat mendegradasi pirena (Isaac et al., 2015). Adapun dari kelompok $\gamma$-proteobacterial, Cycloclasticus, merupakan bakteri yang terkenal sebagai pendegradasi turunan PAH yang terklorinasi (Yakimov et al., 2007). Cycloclasticus yang diisolasi dari Gulf Mexico juga dilaporkan dapat 
menggunakan fenantrena dan naftalena sebagai sumber karbon (Geiselbrecht et al., 1998).

\section{DEGRADASI PLASTIK}

Plastik merupakan senyawa kimia yang tersusun atas polimer rantai panjang. Penggunaan plastik yang menguntungkan manusia, telah menyebabkan penggunaan yang masif selama 3-4 dekade terakhir. Meskipun memiliki banyak manfaat, penggunaan plastik yang meningkat ini juga berpotensi menyebabkan masalah besar, yaitu pencemaran sampah plastik di lingkungan. Indonesia sebagai penyumbang sampah plastik terbesar kedua di dunia, dengan luas lautan di Indonesia yang melebihi $70 \%$ wilayah, menyebabkan potensi cemaran plastik ke perairan laut semakin besar. Oleh karena itu, sampah plastik telah menjadi ancaman besar bagi lingkungan perairan laut Indonesia.

Dekade terakhir ini, sampah plastik telah mengganggu lingkungan laut. Sampah plastik yang ditemukan mengambang di laut menjadi kontaminan terbesar di laut. Berdasarkan penelitian Eriksen et al. (2014), ditemukan minimal sebanyak 5,25 triliun plastik dengan berat sekitar 268.940 ton di belahan dunia selatan. Beberapa jenis plastik yang banyak digunakan dan mencemari laut diantaranya adalah polyethylene terephthalate (PET), high-density polyethylene (HDPE), polyvinyl chloride (PVC), low-density polyethylene (LDPE), dan polystyrene (PS). Dari segi ukuran, plastik dibedakan menjadi mikroplastik $(<4,75 \mathrm{~mm})$ dan makroplastik $(<4,75$ $\mathrm{mm})$ (Eriksen et al., 2014).

Beberapa penelitian telah dilakukan dalam upaya menangani sampah plastik, diantaranya skrining bakteri pendegradasi plastik. LDPE yang banyak dimanfaatkan sebagai kantong kresek dan kantong plastik tipis digunakan sebagai media skrining bakteri. Studi tentang degradasi plastik oleh bakteri yang dilakukan oleh Harshvardhan \& Jha (2013) menunjukkan bahwa tiga isolat yang diidentifikasi sebagai Kocuria palustris M16 (99\% homologi), Bacillus pumilus M27 (99\% homologi), dan Bacillus subtilis H1584 (100\% homologi), mampu menggunakan polietilen sebagai sumber karbon dalam media Bushnell Hazz. Pengamatan SEM (scanning electron microscope) juga menunjukkan adanya perubahan pada struktur polietilen yang diinokulasi dengan menggunakan ketiga bakteri (Harshvardhan \& Jha, 2013). 

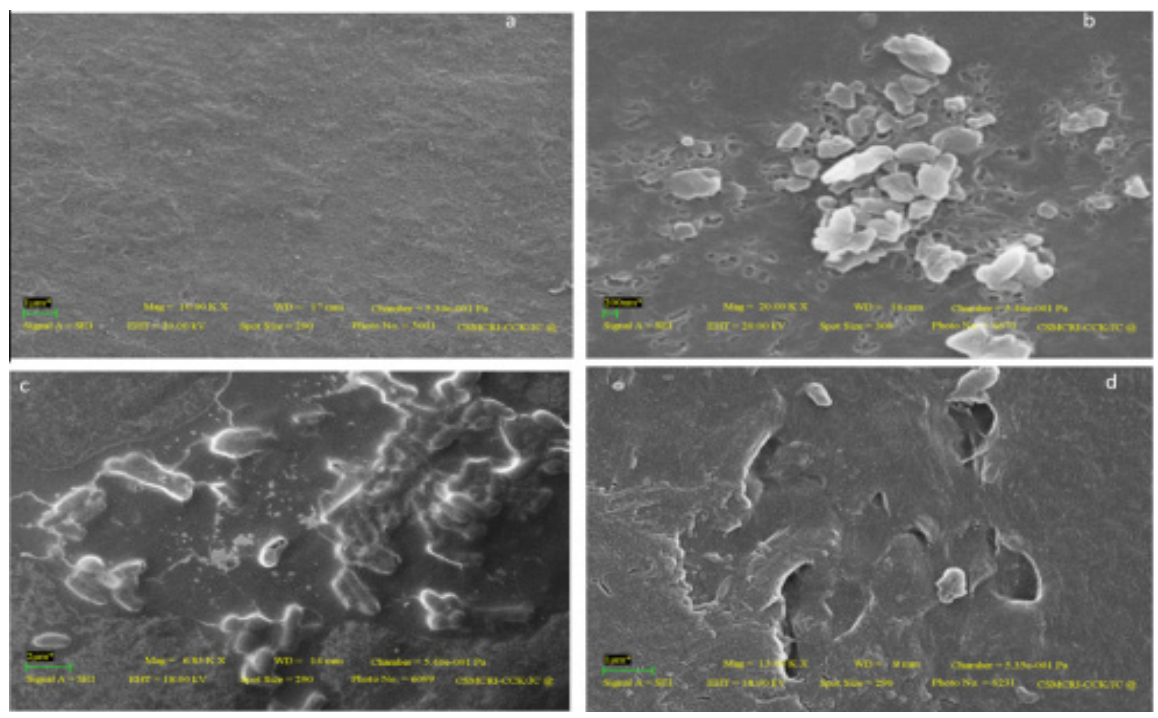

Gambar 1. Visualisasi hasil analisis SEM pada permukaan polietilen setelah 30 hari (a) tanpa inokulasi bakteri, (b) diinokulasi K. palustris M16, (c) diinokulasi $B$. pumilus M27 dan (d) diinokulasi B. subtilis H1584 (Harshvardhan \& Jha, 2013).

Penelitian Kathiresan (2003), menunjukkan bahwa beberapa isolat bakteri yang diisolasi dari sedimen mangrove Rhizophora sp. dan Avicennia sp. memiliki kemampuan mendegradasi polietilen dan plastik. Isolat bakteri yang diprediksi sebagai Pseudomonas sp. memiliki kemampuan mendegradasi 20,54\% polietilen, sedangkan Moraxella sp. mendegradasi $8,16 \%$ plastik dalam satu bulan percobaan. Uji coba degradasi plastik secara in situ yang ditanam dalam sedimen menunjukkan laju degradasi yang sangat lambat, hanya sekitar $0,17-0,25 \%$ dalam 9 bulan. Sekiguchi et al.(2010), juga telah mengisolasi 13 isolat bakteri pendegradasi poly \&-caprolactone (PCL) dari laut dalam di Kurile dan Jepang pada kedalaman antara $5000-7000 \mathrm{~m}$. Ketigabelas isolat bakteri mewakili empat genus, yaitu Shewanella, Moriella, Psychrobacter dan Pseudomonas. Poly E-caprolactone merupakan salah satu jenis plastik yang dapat didegradasi (biodegradable) (Sekiguchi et al., 2010).

\section{DEGRADASI PCB}

POPs atau persistence organics pollutans adalah senyawa organik yang berdampak signifikan bagi kesehatan dan lingkungan, karena sifatnya yang sulit untuk didegradasi. POPs umumnya terakumulasi pada organisme dan karena sifat hidrofobiknya, maka dapat terakumulasi di dalam jaringan lemak (Nikolaivits et al., 2017). Sedimen laut merupakan tempat berakhirnya pencemar persisten seperti polychlorinated biphenyl (PCB), polychlorinated dibenzo-p-dioxin (PCDD), polybrominated diphenylether 
(PBDE), dan 1,1,1-trichloro-2,2-bis(pchlorophenyl)ethane (DDT). PCB merupakan senyawa yang tidak mudah terbakar dan stabil pada suhu tinggi hinga $350^{\circ} \mathrm{C}$. PCB banyak digunakan untuk kebutuhan elektrikal seperti transformer dan kapasitor.

PCB dilaporkan terdeteksi pada kolom air dan sedimen di samudera Antartika (Montone et al., 2001). Michaud et al. (2007), mengisolasi bakteri dari Antartika dan menguji potensinya dalam mendegradasi PCB. Sebanyak 9 dari 126 isolat $(7,1 \%)$ tersebut diketahui mampu menggunakan PCB sebagai sumber karbon, yaitu Pseudoalteromonas, Psychrobacter dan Arthrobacter (Michaud et al., 2007).

Sebelumnya, telah diketahui bahwa Dehalobium chlorocoercia DF-1 yang ditambahkan dalam mesokosm sedimen estuari, dapat meningkatkan deklorinasi PCB (Payne et al., 2001). Uji coba bioaugmentasi Dehalobium chlorocoercia DF1 pada mesokosm mengandung sedimen tercemar dari Pelabuhan Baltimore USA, mampu menurunkan $56 \%$ PCB selama 120 hari (Payne et al., 2011). Sedangkan kombinasi antara bakteri anaerob Dehalobium chlorocoercia DF1 dan bakteri aerob Burkholderia xenovorans LB400 mampu mereduksi PCB hingga 80\% (Payne et al., 2013).

\section{BIOADSORPSI LOGAM BERAT}

Logam berat $\mathrm{Hg}^{2+}, \mathrm{Pb}^{2+}$, dan $\mathrm{Cd}^{2+}$, merupakan logam yang termasuk dalam daftar polutan US EPA karena sifatnya yang non-biodegradable dan toksik. Ketiganya telah diketahui dapat menyebabkan kerusakan organ pada manusia, seperti merkuri yang sangat berbahaya bagi lingkungan perairan dan manusia dalam kasus di Teluk Minamata, Jepang. Merkuri dapat masuk ke rantai makanan dalam bentuk metil merkuri melalui biomagnifikasi. Bakteri laut relatif tahan terhadap kadar merkuri yang tinggi atau biasa disebut dengan BHRM (bacteria highly resistant to mercury). Bakteri resisten senyawa organik merkuri bertahan melalui mekanisme mer operon. Gen merA dan merB merupakan gen yang pengkode mercuric ion reductase dan organomercurial lyase, sebagai bagian dari mer operon. Lyase berperan mereduksi senyawa organik merkuri yang bersifat toksik seperti metil merkuri dan fenil merkuri asetat. Bakteri resisten logam berat yang memiliki mer operon ini berpotensi untuk aplikasi remediasi logam berat melalui biosorpsi yang melibatkan biomassa bakteri (De et al., 2008).

Enterobacter cloaceae, bakteri resisten logam yang diisolasi dari Pantai Barat India, menghasilkan eksopolisakarida yang dapat mengikat berbagai jenis logam berat, diantaranya $65 \%$ kromium, $20 \%$ tembaga, dan $8 \%$ kobalt pada larutan dengan konsentrasi $100 \mathrm{mg} / \mathrm{L}$ logam berat namun tidak dapat mengikat merkuri (Iyer et al., 2005). Vibrio harveyi juga mampu mengakumulasi kadmium hingga $23,3 \mathrm{mg} \mathrm{Cd}{ }^{2+} / \mathrm{gram}$. Pseudomonas, Escherichia, Bacillus, Desulfovibrio, Desulfomicrobium dan Desulfotomaculum diketahui mampu 
mereduksi kromium (Cheung \& Gu, 2003; Jong \& Parry, 2003).

De et al. (2008) menguji kemampuan 11 bakteri BHRM yang termasuk dalam Alcaligenes faecalis, Bacillus pumilus, Pseudomonas aeruginosa, Brevibacterium iodinum, dan Bacillus sp., dalam mereduksi logam berat. A. faecalis, B. pumilus, $P$. aeruginosa, dan $B$. iodinum diketahui memiliki gen merA. Pseudomonas aeruginosa dapat menghilangkan $\mathrm{Cd}$ dalam medium lebih cepat dibanding Alcaligenes faecalis, masing-masing sebesar $75 \%$ dan $70 \% \mathrm{Cd}$ dari konsentrasi awal 100 ppm menjadi 17,4 ppm dan $19,2 \mathrm{ppm}$.

\section{PEMANFAATAN ENZIM BAKTERI LAUT MELALUI REKOMBINASI}

\begin{abstract}
Bioprospeksi produk alam meliputi hewan, tumbuhan dan mikroorganisme tidak terkecuali juga bakteri laut. Enzim yang dihasilkan oleh bakteri merupakan biokatalis yang dapat mempercepat bioproses suatu reaksi. Dalam bioremediasi, penggunaan enzim merupakan salah satu teknik bioaugmentasi. Penggunaan enzim dinilai lebih efektif untuk bioproses, terutama untuk kejadian-kejadian tidak terduga yang membutuhkan penanganan secara cepat, sehingga tidak memerlukan proses kultivasi bakteri terlebih dahulu.
\end{abstract}

Oxygnenase dan dehydrogenase merupakan enzim yang dapat mendegradasi PAH (Haritash \& Kaushik, 2009). Enzim yang dihasilkan oleh bakteri ini berperan dalam mengkatalisis reaksi degradasi senyawa aromatik dan senyawa terhalogenasi. Senyawa aromatik alami umumnya dapat didegradasi oleh beberapa mikroorganisme, namun beberapa senyawa sintetik yang terhalogenasi menyebabkan lebih sulit untuk didegradasi karena kelarutannya yang berkurang.

Enzim phenanthrene deoxygenase (phdABCD dioxygenase) telah berhasil dipurifikasi dari Nocardioides sp. strain KP7 yang diisolasi dari pantai Kuwait yang tercemar minyak. Enzim ini berperan sebagai katalis tahap pertama dalam proses katabolisme fenantrena menjadi o-phthalate (Saito et al., 2000). phdABCD dioxygenase dianggap unik karena secara filogenetik memiliki variasi posisi gen dan komponen ferredoxin yang tidak biasa. Enzim ini tidak hanya dapat mendegradasi fenantrena tetapi juga mengkonversi antrasena dan naftalena. Selanjutnya, Chun et al. (2001) melakukan transformasi gen phdabcd pengkode phdABCD dioxygenase dari strain KP7 tersebut untuk diekspresikan oleh aktinomiset, Streptomyces lividans, bakteri dominan di tanah yang diketahui tidak berperan dalam mendegradasi PAH. Hasil penelitian menunjukkan rekombinan S. Lividans dengan enzim dari bakteri laut ini efektif mendegradasi PAH dan dapat digunakan untuk bioremediasi tanah tercemar PAH. 


\section{PENUTUP}

Pencemaran laut memerlukan penanganan yang tepat agar tidak berkelanjutan dan berdampak fatal bagi ekosistem. Bakteri laut yang berpotensi mendegradasi senyawa-senyawa pencemar telah dieksplorasi dalam beberapa tahun terakhir. Manipulasi genetika terhadap gen yang dikode oleh bakteri laut juga telah dilakukan. Hasil eksplorasi ini memerlukan pengembangan ke arah uji coba skala yang lebih besar seperti mikrokosm dan mesokosm untuk mengetahui efektivitas dan efisiensi aplikasi pemanfaatan bakteri laut dalam mengatasi pencemaran perairan.

\section{DAFTAR PUSTAKA}

Barnum, S.R. 2005. Biotechnology : an introduction. Belmont, CA: Thomson Brooks/Cole. hlm: 138-139.

Cheung, K. H. and J.D. Gu. 2003. Reduction of chromate $\left(\mathrm{CrO}_{4}{ }^{2-}\right)$ by an enrichment consortium and an isolate of marine sulfate-reducing bacteria. Chemosphere, 52 (9): 15231529. doi.org/10.1016/S00456535(03)00491-0.

Chun, H. K., Y. Ohnishi, N. Misawa, K. Shindo, M. Hayashi, S. Harayama and S. Horinouchi. 2001. Biotransformation of phenanthrene and $1-$ methoxynaphthalene with Streptomyces lividans cells expressing a marine bacterial phenanthrene dioxygenase gene cluster. Bioscience, Biotechnology, and Biochemistry, 65 (8): 17741781.

Dash, H. R., N. Mangwani, J. Chakraborty, S. Kumari and S. Das. 2013. Marine bacteria: potential candidates for enhanced bioremediation. Applied Microbiology and Biotechnology, 97 (2): 561571. doi.org/10.1007/s00253012-4584-0.

De, J., N. Ramaiah and L. Vardanyan. 2008. Detoxification of toxic heavy metals by marine bacteria highly resistant to mercury. Mar Biotechnol, 10: 471-477. doi.org/10.1007/s10126-0089083-z.

Eriksen, M., L. C. M. Lebreton, H. S. Carson, M. Thiel, C. J. Moore, J. C. Borerroand and J. Reisser. 2014. Plastic pollution in the world's oceans: more than 5 trillion plastic pieces weighing over 250,000 tons afloat at sea. PLOS ONE, 9(12): e111913. doi.org/10.1371/journal. pone. 0111913 .

Fahruddin, C. 2004. Dampak tumpahan minyak pada biota laut. University of Indonesia.

Geiselbrecht, A. D.,B. P. Hedlund, M. A.Tichi and J. T. Staley.1998. Isolation of marine polycyclic aromatic hydrocarbon (PAH)- 
degrading Cycloclasticus strains from the Gulf of Mexico and comparison of their PAH degradation ability with that of puget sound Cycloclasticus strains. Applied and Environmental Microbiology, 64 (12): 4703-4710.

Harshvardhan, K. and B. Jha. 2013. Biodegradation of lowdensity polyethylene by marine bacteria from pelagic waters, Arabian Sea, India. Marine Pollution Bulletin, 77: 100-106. doi.org/10.1016/J. MARPOLBUL.2013.10.025

Isaac, P., M. Lozada, H. M. Dionisi, M. C. Estévez and M.A. Ferrero. 2015. Differential expression of the catabolic nahAc gene and its effect on PAH degradation in Pseudomonas strains isolated from contaminated Patagonian coasts. International Biodeterioration \& Biodegradation, 105: 1-6.

Iyer, A., K. Mody and B. Jha. 2005. Biosorption of heavy metals by a marine bacterium. Marine Pollution Bulletin, 50 (3): 340343.

Jong, T. and D. L. Parry. 2003. Removal of sulfate and heavy metals by sulfate reducing bacteria in short-term bench scale upflow anaerobic packed bed reactor runs. Water Research, 37 (14): 3379-3389. doi.org/10.1016/ S0043-1354(03)00165-9.
Leung, M. 2004. Bioremediation: techniques for cleaning up a mess. Journal of Biotechnology, 2: $18-22$.

Madigan, M. T., J. M. Martinko,P. V. Dunlap and D.P. Clark. 2008. Brock's Biology of Microorganisms (12th ed.). San Fransisco: Pearson Benjamin Cummin.

Michaud, L., G. Di Marco, V. Bruni and A. Lo Giudice. 2007. Biodegradative potential and characterization of psychrotolerant polychlorinated biphenyl-degrading marine bacteria isolated from a coastal station in the Terra Nova Bay (Ross Sea, Antarctica). Marine Pollution Bulletin, 54 (11): 1754-1761.

Montone, R. C., S. Taniguchi and R. R. Weber. 2001. Polychlorinated biphenyls in marine sediments of Admiralty bay, King George Island, Antarctica. Marine Pollution Bulletin, 42 (7): 611614. doi.org/10.1016/S0025326X(01)00092-3.

Nikolaivits, E., M. Dimarogona, N. Fokialakis and E. Topakas. 2017. Marine-derived biocatalysts: importance, accessing, and application in aromatic pollutant bioremediation. Frontiers in Microbiology, 8: 265. doi.org/10.3389/ fmicb.2017.00265. 
Payne, R. B., S. K. Fagervold, H. D. May and K. R. Sowers. 2013. Remediation of polychlorinated biphenyl impacted sediment by concurrent bioaugmentation with anaerobic halorespiring and aerobic degrading bacteria. Environmental Science \& Technology, 47 (8): 3807-3815. doi.org/10.1021/es304372t.

Payne, R. B., H. D. May and K.R. Sowers. 2011. Enhanced reductive dechlorination of polychlorinated biphenyl impacted sediment by bioaugmentation with a dehalorespiring bacterium. Environmental Science \& Technology, 45 (20): 87728779 . doi.org/10.1021/ es201553c.

Saito, A., T. Iwabuchi and S. Harayama. 2000. A novel phenanthrene dioxygenase from Nocardioides sp. strain KP7: expression in Escherichia coli. Journal of Bacteriology, 182 (8): 21342141.
Sekiguchi, T., T. Sato, M. Enoki, H. Kanehiro, K. Uematsu and C. Kato. 2010. Isolation and characterization of biodegradable plastic degrading bacteria from deepsea environments. Rep. Res. Dev, 11: 33-41.

Teramoto, M., M. Ohuchi, A. Hatmanti, Y. Darmayati, Y. Widyastuti, S. Harayama and $\mathrm{Y}$. Fukunaga. 2011. A bacterium that degrades petroleum aliphatic hydrocarbons in a tropical marine environment. International Journal of Systematic and Evolutionary Microbiology, 61: 375-380. doi.org/10.1099/ijs.0.0186710 .

Yakimov, M. M., K. N. Timmi and P. N. Golyshin. 2007. Obligate oil-degrading marine bacteria. Current Opinion in Biotechnology, 18 (3): 257-266. doi.org/10.1016/J. COPBIO.2007.04.006. 